\title{
Memasarkan Tradisi: Klasifikasi Kegunaan Twitter dalam Festival Budaya
}

\author{
Yudo Hartono ${ }^{1}$, Peni Zulandari ${ }^{2}$ \\ 'Universitas Prasetiya Mulya \\ yudo.hart@pmbs.ac.id \\ Universitas Prasetiya Mulya \\ peni.zulandari@pmbs.ac.id
}

\begin{abstract}
The use of social media in promoting traditional selebration such as cultural festival is relatively new used by festival organizer. Twitter as one of social media can be effective if is used in cultural festival because it is perceived not only able to raise the audience awareness, but also able to involve many visitors to interact each others This research is focusing on how to describe the words that is used in Twitter and analizing the use of Twitter in promoting this festival. The analysis will be focused on word analysis and many comments will be processed by using computer software called Ripple 10. The result of this research can be used to evaluate, create decision to improve the festival quality in the future.
\end{abstract}

Keywords: twitter; cultural festival, visitors 


\section{PENDAHULUAN}

Cap Go Meh di Bogor identik dengan perayaan dimana dilakukan pada hari terakhir masa perayaan Tahun Baru Imlek. Selama 15 hari setelah tahun baru, umat dapat bersilahturahmi untuk saling mengunjungi sanak keluarga. Setelah hari ke-15 tidak diperkenankan lagi untuk adanya perayaan. Jika mengikuti sejarah dari nenek moyang di China, hari ke-16 adalah waktunya untuk kembali bekerja, yaitu bercocok tanam. Perayaan Cap Go Meh adalah tradisi untuk memberikan blessing bagi masyarakat sekitar. Bagaimana mengubah cara berpikir bahwa beragama bukan hanya memberikan kebaikan bagi agamanya sendiri, tapi juga bagi umat lain. Inilah yang mendasari bahwa Perayaan Cap Go Meh digambarkan perayaan yang besar namun intinya memberikan manfaat bagi orang banyak

Sebagai sebuah perayaan tradisi tentunya Festival Cap Go Meh Bogor diharapkan oleh panitia penyelenggara dan Walikota Bogor dapat menjadi sebuah destinasi tidak hanya acaranya saja namun juga menikmati kota Bogor. Di tahun 2015, Festival Cap Go Meh di kota Bogor memperluas konsep acaranya dengan menggunakan nama Bogor Street Festival. Hal ini menyebabkan festival tersebut semakin membutuhkan peranan media sosial didalam upayanya untuk meningkatkan awareness dan juga membangun engagement para partisipan atau pengunjungnya.

Penggunaan media sosial ini juga dapat dilihat melalui penelitian yang dilakukan oleh Xiang \& Gretzel ditahun 2010, mengatakan bahwa pemasar di bidang pariwisata tidak lagi bisa mengabaikan peran media sosial di setiap kegiatannya. Terutama bagi kaum muda dibawah usia
34 tahun, platform media sosial mendominasi penggunaan internet (Chappuis, Gaffey, \& Parvizi, 2011).

Twitter menjadi menarik untuk dianalisis karena Twitter sendiri menjadi salah satu situs media sosial yang paling cepat pertumbuhannya dimana sejak peluncurannya 21 Maret 2006 dengan memiliki memiliki 288 juta pengguna aktif dengan hampir sekitar 500 juta twit yang terkirim dalam sehari dan memiliki $77 \%$ akun yang berada diluar AS serta $80 \%$ pengguna aktif mengakses twitter melalui perangkat gawai bergeraknya. (www.twitter.com diakses pada Maret 2015).

Laman Social Media Today menilai bahwa Twitter adalah platform termudah dari seluruh media sosial yang ada. Meskipun terdapat limitasi 140 karakter dalam satu kali memposting, hal tersebut bukan halangan bagi penggunanya untuk membagi tautan, foto, berita, dan bahkan berkomunikasi dengan idolanya. Twitter juga mempunyai fitur trending topic, yang memperlihatkan topik pembicaraan terhangat di seluruh dunia dalam waktu riil yang bersamaan. Trending ini juga dapat dilihat secara global maupun lokal.

Penggunaan media sosial untuk membantu penyebaran informasi Cap Go Meh ini terutama melalui Twitter juga ditandainya dengan beberapa akun Twitter yang terlibat seperti @CgmFest, @PemkotaBogor, @infobogor dan juga terdapat@kisiFMBogor.

\section{Festival Sebagai Fenomena Sosial dan Budaya}

UNESCO memberikan definisi festival sebagai perayaan publik yang memiliki tema tertentu dimana didalamnya terdapat ekspresi dari sebuah event 
budaya. Bagi sebuah kelompok masyarakat, festival dijadikan sebagai ajang penting untuk mempertunjukkan budaya dan kreativitasnya. Menurut Getz (2008), festival sebagai salah satu bentuk dari perayaan kultural dapat dikemas dalam berbagai macam bentuk program yang bervariasi, dimulai dari pertunjukan seni baik yang bertemakan agrikultur atau alam, hiburan, kuliner, atau kombinasinya. Secara umum, festival dapat menjadi sebuah ekspresi manusia yang sangat penting dan memiliki kontribusi besar terhadap kehidupan sosial dan kultural.

Frey (1994) menyebutkan bahwa festival merupakan sebuah fenomena budaya yang kompleks dengan memiliki banyak bagian-bagian (multifacet) serta merefleksikan proses budaya yang aktif karena memiliki identitas dan struktur yang bersifat institusional. Sementara, Throsby (2003) mengatakan bahwa nilai dari sebuah festival budaya mencakup bagaimana sebuah produk budaya itu dibuat dan berdampak pada pengunjung seperti nilai estetika, penikmatan, hiburan dan nilai kognitif, serta terdapat pula nilai risiko (value of repercussion) yang akan diterima oleh pengunjung dan memiliki kecenderungan untuk disimpan dalam memori pengunjung untuk jangka waktu yang lama dan panjang. Del Barrio, Devesa, \& Herrero (2012) mengatakan festival budaya juga memiliki keuntungan bagi pengambil kebijakan seperti pemerintah di daerah terutama yang terkait dengan dampak ekonomi dari sebuah festival dan dampak lain yang bersifat laten atau tidak kelihatan (intangible) ketika festival tersebut diselenggarakan.

Festival sebagai salah satu fenomena sosial dan budaya secara tidak langsung memenuhi fungsi sosial dan budaya didalam sebuah masyarakat kontemporer seperti mampu menarik pengeluaran pengunjung, membentuk citra baru karakteristik masyarakat urban, dan sebagai kekuatan dibalik kreatifitas budaya dan kohesi sosial. Bahkan Allen, O'Toole, \& McDonnell (2008) mengatakan bahwa sebuah kota dapat mengekspresikan karakter serta keunikan kotanya melalui festival. Hal inilah yang mendorong pertumbuhan festival yang terjadi baik di kota-kota ataupun desa.

\section{Pengalaman Memasarkan Festival dengan Twitter.}

Tidak mudah mencari literatur yang secara spesifik membahas terkait dengan media sosial seperti yang diutarakan oleh Mangold dan Faulds (2009) sehingga tidak banyak arahan yang dapat membantu para manajer misalnya untuk menggunakan media sosial didalam strategi komunikasinya. Namun meskipun demikian Kaplan dan Haenlen (2010) sudah memberikan suatu titik terang bahwa media sosial dapat digunakan untuk mengarahkan diskusi yang terjadi dengan konsumen. Penelitian yang dilakukan oleh Sparkloft Media di tahun 2011 juga menyatakan bahwa penggunaan media sosial dalam konteks penyelenggaraan festival masih terbatas dan biasanya lebih terfokus kepada penggunaanya dalam konteks DMO (Organisasi Pemasaran Destinasi) dimana tujuannya lebih kepada meningkatkan awareness bagi destinasi tersebut dan untuk membangun engagement dengan pengunjungnya. Meski demikian, berikut terdapat beberapa penggunaan Twitter pada festival musik meski tidak spesifik pada festival budaya yang dilakukan oleh Hudson dan Hudson (2013), namun paling tidak penggunaannya dapat 
dijadikan sebagai referensi didalam penelitian ini.

Penggunaan Twitter pada festival music Bannaro di Manchester, Tennessee, AS menunjukkan bahwa festival ini merupakan festival musik dengan penekanan kepada musik-musik dengan aliran seperti Indie Rock World Music, Hip Hop, Jazz, Americana, Bluegrass, Country, Reggae dan lain-lain. Festival ini tidak hanya fokus pada para pemusik namun juga melibatkan para pekerja seni yang menjual produk-produk unik, dan area yang berisikan makanan dan minuman. Penggunaan Twitter yang berhasil terlacak pada festival ini berdasarkan kajian yang dilakukan oleh Wadhwani (2012) adalah beberapa katakata teratas yang sering disebut pada acara Festival Bannaroo tersebut seperti keramaian (crowd), hippies, shower, sleep, beer, camping dan lumpur (mud), sementara kata-kata yang terkait dengan fashion yang muncul adalah bathing suit, costume, tie dye sementara kata-kata slang yang digunakan adalah awesome, dude, sick, killer dan dope!

Berbeda dengan festival diatas maka Festival Lattitude di Suffolk, Inggris Raya yang penekanan eventnya sebenarnya lebih memasukkan berbagai elemen seperti teater, art, komedi, cabaret, puisi, dansa dan lain-lain. Penggunaan Twitter pada acara festival ini lebih menekankan kepada hubungan dan komunikasi dengan pengunjung yang digunakan untuk memberikan informasi mengenai perkembangan terbaru dari acara ini. Penggunaan Twitter juga lebih ditekankan sebagai pengingat bagi para pengunjung agar mereka tetap mendatangi acara meskipun kondisi cuaca yang tidak mendukung. Sebagai salah satu contoh kalimat yang digunakan di Twitter adalah "News just in-the traffic is moving along nicely and there are currently no queues [...] hurry up and let's get Latitude 2012 started!" Hasilnya disebutkan oleh panitia adalah dengan menggunakan bahwa platform media sosial mereka dapat dikatakan sangat sukses dengan banyaknya jumlah subscriber seperti banyaknya likes, fans, followers' dan lain-lain. Pada saat penelitian Hudson dan Hudson ini dilakukan tercatat jumlah followers pada Twitter adalah sebesar 33,328 akun.

Sementara itu Festival Lollapalooza di Chicago, Amerika Serikat dihadiri oleh pengunjung dengan kisaran 10.000 orang pada tahun 2012. Festival ini lebih selektif dalam menggunakan media sosialnya yaitu Facebook dan Twitter yang digunakannya secara kreatif didalam membangun hubungannya dengan pengunjung. Festival ini secara kreatif memanfaatkan hashtag atau (biasa dikenal dengan menggunakan simbol seperti ini: \# ) yang merupakan salah satu cara di Twitter untuk mengelompokkan keywords atau topik yang sedang diangkat. Salah satunya adalah menampilkan potongan dari lirik yang digunakan oleh band yang akan tampil pada festival ini. Hasilnya feedback dari pengguna Twitter sangatlah terasa, mereka banyak melakukan posting di Twitter baik berbentuk tulisan terkait festival ataupun foto-foto yang terkait dengan acara tersebut.

$\begin{aligned} & \text { Keberadaan festival sepanjang } \\ & \text { penelusuran penulis } \\ & \text { memberikan manfaat bagi }\end{aligned}$
$\begin{aligned} & \text { bestinasi } \\ & \text { seperti pembentukan }\end{aligned}$
menciptakan posisi daerah untuk
menjadi lebih kompetitif sampai
dampak ekonomi bagi daerah
tersebut. Keberadaan media sosial
seperti halnya Twitter digunakan oleh


pengelola festival disamping untuk mendapatkan pengunjung diharapkan pula seperti yang dikatakan oleh Hudson, Roth, Madden dan Hudson (2015) untuk mendokumentasikan pengalaman yang didapatkan pada saat festival berjalan sementara Oliveira dan Panyik (2015) menambahkan bahwa media sosial dapat menciptakan getok tular melalui online yang dapat meningkatkan keterikatan pengunjung pada festival di dunia maya. Namun tantangannya pada festival, menurut penulis adalah masih banyaknya pengelola festival terutama di Indonesia belum serius didalam mengembangkan pemasaran festival melalui media sosial. Media sosial hanya dilihat sebagai pelengkap promosi sehingga akhirnya hasil atau dampak positif yang diharapkan terkadang belum maksimal apabila dibandingkan dengan tujuan awal yang ingin dicapai.

\section{METODE}

Proses pemantauan di media sosial dapat dilakukan dengan proses yang disebut sebagai "tracking" atau penelusuran setelah fenomena yang berkembang dan yang ingin diteliti berhasil teridentifikasi. Dalam konteks pemantauan yang terjadi pada Twitter adalah dengan menggunakan software yang bernama Ripple10 dengan proses yang dilakukan adalah mengelompokkan kata kunci yang kemudian akan dianalisis dengan menggunakan analisis kata mengingat temuan data dari media sosial biasanya merupakan data yang tidak terstruktur.

Prosesnya sendiri digambarkan secara sederhana bahwa percakapan dalam Twitter yang terjadi kemudian difokuskan dengan secara spesifik untuk mencari kata kunci seperti capgomeh,
CGM, bogorstreetfestival, capgomehbogor, cgmbogor sehingga data yang dihasilkan oleh software ini. Langkah selanjutnya adalah mengeliminasi noise sehingga meskipun data yang didapatkan masih bersifat tidak terstruktur namun sudah dapat digunakan untuk tahap selanjutnya yaitu analisis.

Analisis yang dilakukan kurang lebih sama dengan yang dilakukan oleh Chae (2014) yaitu dengan menggunakan salah satu analisis konten dengan fokus kepada analisis kata dimana kata yang sering keluar pada Twitter dengan menggunakan Ripple10. Pengelompokkan kata kemudian dilakukan dengan menjadi dasar untuk menentukan kegunaan Twitter didalam memasarkan festival budaya.

\section{PEMBAHASAN}

Secara keseluruhan analisis dapat dilihat dengan menggunakan sebuah grafik yang dihasilkan dari pemantauan buzz (buzz monitoring). Secara umum buzz dapat diartikan seperti suara pada kerumunan yang biasa ditemukan pada serangga dan menjadi kata yang biasa digunakan untuk melihat "suara netizen atau pengguna aktif di internet" pada suatu platform online atau internet. "Suara" atau percakapan inilah yang kemudian direkam dengan melakukan penelusuran sejak tanggal 22 Februari 2015 sampai dengan tanggal 18 Maret. Dari gambar di bawah tampak puncak percakapan terjadi pada tanggal 5 Maret 2015 yang memang menjadi acara puncak dari Festival Cap Go Meh itu sendiri dengan tweet atau kicauan yang mencapai 227 konten percakapan. 


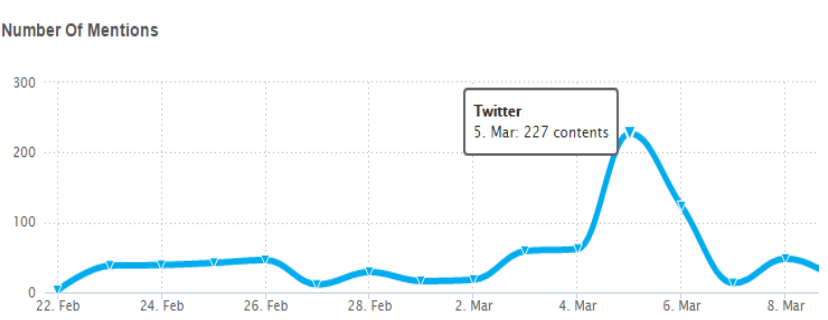

Dari pola grafik diatas tampak diskusi percakapan di Twitter terekam eskalasi percakapan menunjukkan tren naik setelah tanggal 2 Maret 2015 dan menurun drastis setelah tanggal 6 Maret dengan intensitas percakapan dibawah 100 tweets atau cuitan. Grafik diatas tentunya memberikan gambaran bahwa festival ini mendapatkan perhatian di Twitter, namun yang menarik untuk dianalisis adalah puncak dari grafik diatas hanya terjadi pada saat acara berlangsung. Namun penurunan yang cukup tajam terjadi di hari pertama setelah acara selesai yaitu ditanggal 6 Maret 2015.

Meski belum terlalu detail dapat memberikan gambaran, namun aktivitas cuitan yang begitu besar terjadi pada saat hari berlangsungnya festival menunjukkan bahwa aktivitas tertinggi pada Twitter yang didapat memberikan informasi mengenai aktivitas tweets yang berlangsung dalam rentang waktu tertentu. Hasil diskusi dengan para penyelenggara festival seringkali menyebutkan aktivitas promosi suatu festival atau event biasanya sekitar dua minggu sebelum hari berlangsungnya festival atau event dan obrolan para pengunjung setelah event selesai juga diambil sekitar dua minggu setelah event tersebut berlangsung.

Aktivitas Twitter apabila dari analisis kata, bisa dieksplorasi melalui kata-kata yang terekam dalam Twitter sebelum, pada saat festival tersebut berlangsung dan sesudah acara selesai. Beberapa kata yang muncul dan menarik untuk dianalisis misalnya terkait dengan peta dan ajakan untuk memeriahkan acara yang terekam dan kata-kata ini muncul sebanyak 30 dan 29 kali. Gambaran banyaknya jumlah tweets yang muncul dapat dilihat dari tabel dibawah ini

Tabel 1

Kata Terekam Sebelum Festival Cap Go Meh Bogor 2015

\begin{tabular}{|l|l|c|}
\hline No & \multicolumn{1}{|c|}{ Kata Terekam } & Jumlah \\
\hline 1 & Peta & 30 kali \\
\hline 2 & Ayo Meriahkan & 29 kali \\
\hline 3 & Pra Event & 29 kali \\
\hline 4 & Press Conference & 26 kali \\
\hline 5 & Kompetisi Barongsai & 23 kali \\
\hline
\end{tabular}

Dari tabel 1 dapat terlihat kata "Peta" merupakan kata yang paling sering muncul. Hal ini dirasakan menjadi hal yang penting dan wajar digunakan sebagai bagian dari sosialisasi mengenai kegiatan Festival Cap Go Meh Bogor 2015 ini. Sebagaimana diketahui acara ini seperti pada tahun-tahun sebelumnya menggunakan sepanjang jalan Suryakencana di Kota Bogor dan pada tahun 2015 rute perjalanan ditambah dengan menggunakan Jalan Pajajaran sebagai rangkaian kegiatan festival sehingga rute peta menjadi sangat krusial untuk disosialisasikan agar tidak terjadi kebingungan untuk orang-orang yang ingin berkunjung ke Bogor mengingat hal ini baru pertama kalinya terjadi acara seperti Cap Go Meh ini.

Sementara kata Ayo Meriahkan mendapatkan jumlah sebanyak 29 kali seperti yang tertulis dibawah ini 
“Ayo Meriahkan @CgmFest-

BogorStreetFest-Pesta Rakyat

Bogor! Kamis, 5 Maret, 2015

\#CGMBogor"

Apabila dari kata-kata diatas dapat diamati bahwa penekanan dari kata-kata ini lebih bersifat ajakan dan kalimat tersebut banyak muncul maka aktivitas media sosial melalui Twitter ini serupa dengan apa yang terjadi pada Festival Bannaroo dengan banyaknya kalimat yang bersifat ajakan sehingga fungsi Twitter sebagai platform promosi yang dilakukan oleh para pengelola festival bersama dengan mitranya.

Sementara berikut ini disarikan pada tabel 2 yang diambil dari Twitter terkait dengan informasi yang didapat pada hari pelaksanaan festival. Beberapa hal menarik adalah terkait dengan informasi terkait fitur dari festival seperti panggung dan pengisi acara seperti yang disajikan dalam tabel yaitu sejenis ondelondel yang berasal dari Taiwan.

Tabel 2

Kata Terekam pada Saat Festival Cap Go Meh 20115

\begin{tabular}{|c|l|c|}
\hline No & Kata Terekam & Jumlah \\
\hline 1 & Panggung & 23 Kali \\
\hline 2 & Jokowi & 16 Kali \\
\hline 3 & $\begin{array}{l}\text { Ondel-ondel } \\
\text { Taiwan }\end{array}$ & 11 Kali \\
\hline 4 & Ayo Meriahkan & 11 Kali \\
\hline 5 & Presiden & 10 Kali \\
\hline
\end{tabular}

Dari tabel 2 data yang diambil adalah pada saat diselenggarakannya festival ini ternyata menyebutkan bahwa kata panggung menjadi kata yang paling banyak muncul pada Twitter. Salah satu kata yang paling banyak muncul adalah kata "panggung". Pada festival ini ternyata dilakukan dengan tempat yang berbeda-beda di setiap spot-spot tertentu dan pada tanggal 5 Maret ini, Festival Cap Go Meh ini memiliki delapan panggung yang masing-masing memiliki karakteristik acara-acara yang berbedabeda dan menjadi salah satu keunikan dari keberadaan festival ini sendiri. Salah satu tweet yang Twitter yaitu mengenai panggung yang terdapat pada acara festival ini. Kata-kata seperti "Kemeriahan di panggng seberang Vihara Dharmakaya \#CGMFest2015! Makin malam makin ramai@CgmFest" mendapatkan retweet yang banyak dari para pengguna Twitter

Kata Jokowi ternyata muncul cukup banyak intensitasnya didalam aktivitas tweet di linimasa Twitter. Namun tampaknya kata Jokowi sebagai seorang public figure lebih sering muncul dibandingkan dengan Jokowi sebagai presiden. Sepertinya pengunjung terutama pengguna Twitter nama Jokowi jauh lebih popular dibandingkan kata presiden itu sendiri. Jokowi juga menjadi salah satu daya tarik di linimasa Twitter yang dapat dilihat dari jumlah retweet para pengguna Twitter. Hal ini menunjukkan bahwa pada saat itu kedatangan presiden Jokowi ke acara Cap Go Meh tentu menarik orang untuk melihatnya secara langsung atau live. Beberapa kalimat yang menggambarkan mengenai Presiden Jokowi adalah sebagai berikut:
“@infobogor:linimasa Bapak
@jokowi_do2 membuka helaran
PESTA RAKYAT BOGOR
\#CGMFest2015!@CgmFest"
“@CGMFest: live streaming CGM
2015 bersama Presiden Jokowi
pukul 15.3021 .00 \#cgmbogor" 
Sementara dari tiga besar cuitan di Twitter adalah adanya karakter boneka yang di linimasa disebut sebagai ondelondel yang berasal dari negara Taiwan. Ondel-ondel Taiwan ini sendiri menjadi daya tarik lain dari keberadaan festival ini yang uniknya lebih sering muncul dalam linimasa di Twitter dibandingkan dengan Barongsai yang biasanya selalu mendominasi di acara-acara seperti Cap Go Meh. Paling tidak akun seperti @infobogor dan@ @EHBogor menggambarkan uniknya festival dengan keberadaan ondel-ondel Taiwan ini:

@infobogor: Ondel-ondel
Taiwan "Lo Cia San Tai Cu Dance
ikut memeriahkan pawai PESTA
RAKYAT BOGOR \#CGMFest2015
@EHBogor: Ondel-ondel Taiwan
moodbooster buat kita di acara
@CgmFest \#CGMFEST2015

Keunikan peserta yang ikut berpartisipasi dalam Festival Cap Go Meh yang berasal dari negara lain yang ikut menjadi salah satu pengalaman menarik bagi pengunjung. Apabila dilihat dari jumlah percakapan yang tercatat jauh melebihi penampilan Barongsai yang selalu menjadi ikon setiap acara Cap Go Meh berlangsung. Aktivitas perekaman aktivitas percakapan juga dilakukan beberapa hari setelah acara festival selesai dimana pencatatan jumlah kata tersebut dapat dilihat pada tabel dibawah ini:

Tabel 3

\section{Kata Terekam Setelah Festival Cap Go} Meh 2015

\begin{tabular}{|c|l|c|}
\hline No & \multicolumn{1}{|c|}{ Kata Terekam } & Jumlah \\
\hline 1 & $\begin{array}{l}\text { Kota Lain Perlu Meniru } \\
\text { Bogor }\end{array}$ & 55 Kali \\
\hline
\end{tabular}

\begin{tabular}{|c|l|c|}
\hline 2 & $\begin{array}{l}\text { Bogor Street Festival. } \\
\text { Cap Go Meh 2015 }\end{array}$ & 32 Kali \\
\hline 3 & Jokowi & 15 Kali \\
\hline 4 & Sampah ditinggalkan & 9 Kali \\
\hline 5 & Presiden & 8 Kali \\
\hline
\end{tabular}

Deskripsi pada tabel 3 yang memperlihatkan kata yang terungkap setelah berlangsungnya festival. Dari tabel dapat dilihat bahwa pendapat yang dikeluarkan oleh Presiden Jokowi pada saat berlangsungnya festival ternyata menjadi salah satu tweet yang paling banyak di-retweet oleh para pengguna Twitter setelah pelaksanaan festival ini selesai. Kesan yang didapat dari tweet ini adalah kalimat yang datangnya dari seorang presiden tentunya memberikan kebanggaan para warganya terhadap kota Bogor. Seperti yang dikutip dari aku @infobogor dibawah ini:

$$
\begin{aligned}
& \text { “...kota-kota lain perlu } \\
& \text { meniruBOGOR-Pak } \\
& \text { @jokowi_do2|@aheryawa } \\
& \text { n@BimaAryas } \\
& \text { @aniesbaswedan }
\end{aligned}
$$

Dominasi tweet dari Presiden Jokowi terasa sekali dari cuitan yang berhasil direkapitulasi. Terbukti dari beberapa kata kunci seperti Jokowi dan Presiden mendominasi banyaknya frekuensi yang muncul dari cuitan para pengguna Twitter. Namun demikian ada satu unggahan mengenai dampak dari festival yang cukup menarik yaitu mengenai sampah. Seperti yang dikutip dari akun@HeiBogor:

\footnotetext{
"Bogor Street Festival Sukses, Sampah ditinggalkan http://t.co/hlPk3sNFXQ \#BeritaBogor
} 
Dominasi tersebut bisa jadi hal yang perlu dipikirkan di masa depan bagi penyelenggara festival semacam Cap Go Meh.

Beberapa temuan diatas memang masih belum sempurna, namun setidaknya bisa menggambarkan mengenai peranan media sosial pada sebuah festival budaya. Apabila mengacu pada temuan diatas paling tidak terdapat beberapa fungsi Twitter yang dapat dijadikan sebagai alasan untuk berbagai festival di Indonesia dapat menggunakan dan memaksimalisasikan penggunaan media sosial khususnya Twitter. Dari hasil analisis pada Festival Cap Go Meh ini setidaknya terdapat beberapa kegunaan Twitter pada pelaksanaan festival budaya, yaitu:

\section{a. Alat Promosi}

Sebagaimana dijelaskan pada banyak literature, peranan media sosial sebagai alat promosi suatu festival ternyata juga ditemukan pada Festival Cap Go Meh ini. Dapat dilihat dari tabel diatas bahwa informasi kata yang terekam pada saat sebelum dan berlangsungnya festival kata-kata yang mengandung ajakan dapat diamati dengan jumlah kata yang tinggi.

b. Penggambaran Situasi dan Suasana Festival

Twitter pada Festival Cap Go Meh ini juga menunjukkan bahwa banyak akun yang memanfaatkan Twitter ini sebagai deskripsi terhadap situasi dan suasana festival. Kata Panggung misalnya menunjukkan bahwa acara ini memiliki banyak panggung dengan variasi acara yang berbeda-beda di setiap panggungnya.

c. Deskripsi Daya Tarik Festival

Twitter pada festival budaya ini juga secara tidak langsung menunjukkan adanya daya tarik festival yang tercermin pada kehadiran tokoh nasional yang kebetulan hadir adalah Presiden Republik Indonesia yaitu Joko Widodo (Jokowi). Kehadiran Jokowi tercermin dalam kata-kata yang muncul seperti Jokowi dan presiden. Uniknya kata-kata ini seakan-akan terpisah yaitu Jokowi sebagai personal dan Jokowi sebagai presiden seakanakan memberikan kesan formal namun informal dengan kehadiran Presiden RI ini. Kedepannya, kehadiran tokohtokoh yang dekat masyarakat apakah mereka adalah tokoh politik ataupun tokoh dari kalangan artis sebenarnya memiliki peranan penting didalam membangun diskusi di media sosial Twitter.

d. Penegas Keberadaan Festival sebagai Identitas Kota

Twitter dalam festival budaya kali ini juga memberikan gambaran penegasan akan identitas kota yang dapat menjadi kebanggaan bagi warga kota tersebut. Dalam kasus Bogor, pernyataan Jokowi yang menjadikan Bogor sebagai contoh pelaksanaan festival budaya yang mampu menyatukan berbagai macam latar belakang ternyata banyak di re-tweets oleh para pengguna media sosial Twitter. 
e. Sinyal Negatif Pelaksanaan
Festival

Ada beberapa cuitan terkait dengan sampah dimana aktivitas setelah festival berakhir maka kemudian sampah begitu banyak ditinggalkan. Hal ini tentunya membuka banyak pertanyaan bagi pengelola bahwa pembiaran pembuangan sampah yang begitu banyak juga merupakan gambaran perilaku pengunjung yang tidak memperdulikan kondisi lingkungan dengan perilakunya membuang sampah secara sembarangan. Tentunya hal ini menjadi pertanyaan serius untuk dijawab kemudian, bahwa terkait sampah, menjadi tanggung jawab pengelola festival kah atau terus mengedukasi pengunjung festival agar tidak terus membuang sampah dengan sembarangan.

Dari temuan diatas tentunya dapat memberikan sedikit gambaran mengenai fungsi Twitter didalam memasarkan suatu festival budaya bahwa ketika suatu media sosial dikelola dengan benar tentunya akan dapat memberikan banyak manfaat. Namun disisi lain pengelolaan yang cenderung kurang profesional juga ditunjukkan dengan minimnya informasi terkait festival tersebut selama lebih dari empat minggu mengamati perubahan percakapan di Twitter terkait Festival Cap Go Meh di Bogor ini. Rendahnya kata-kata yang terekam juga dapat dijadikan sebagai indikasi bahwa pengelola festival belum melihat media sosial sebagai alat bantu yang sebenarnya cukup efektif. Begitu juga kemunculan kata negatif seperti sampah yang berserakan ini juga menjadi tanda tanya bahwa pengelolaan festival nampaknya masih belum melihat kebersihan sebagai salah satu hal wajib yang perlu diperhatikan untuk kenyamanan pengunjung. Namun sebagai pintu awal, Twitter ternyata cukup efektif untuk dapat menunjukkan sedikit banyak warna dari sebuah festival budaya sehingg penggunaan Twitter di masa akan datang dapat membantu pengelola festival untuk berinvestasi secara serius untuk mendapat hasil yang maksimal.

\section{KESIMPULAN}

Memasarkan sebuah festival budaya perlu dievaluasi melalui pemantauan melalui media sosial dimana dalam hal ini adalah Twitter. Mengevaluasi Twitter tentunya dapat menjadi pembuka jalan perbaikan kualitas festival budaya di masa yang akan datang. Dalam konteks penyelenggaraan festival seperti yang terjadi di Festival Cap Go Meh Bogor 2015, dapat dilihat bahwa diskusi dan obrolan yang dilakukan dapat terekam dan secara keseluruhan dapat memberikan informasi baru mengenai beberapa kegunaan Twitter.

Dalam hal ini evaluasi Twitter yang dilakukan ternyata menunjukkan bahwa Twitter tidak hanya sebagai alat promosi saja namun juga sebagai pemberi gambaran terkait dengan situasi dan suasana festival, daya tarik festival dan juga menunjukkan bahwa keberadaan festival sebagai penegas identitas kota dan dalam hal ini Twitter juga mampu memberikan informasi negatif terkait dengan pelaksanaan festival serta atribut menarik yang dapat mendorong terjadinya percakapan di internet ketika seorang pengunjung mendatangi suatu festival.

Beberapa catatan yang dapat menjadi masukan bagi panitia penyelenggara adalah untuk mulai mengoptimalkan media sosial yang dimilikinya mengingat 
masih rendahnya jumlah dan frekuensi percakapan yang terjadi di media sosial ini terutama dalam hal ini adalah Twitter.

\section{REFERENSI}

Allen, J., O'Toole, W., McDonnell, I., \& Harris, R. (2002). Festival and special event management (2nd ed.). Australia, Milton: Wiley.

Branthwaite, A dan Simon Peterson (2011). The power of qualitative research in the era of social media. Qualitative Market Research: An International Journal, Vol 14, no 4, 431

Chae, B. (2015). Insights from Hashtag \#supplychain and Twitter Analytics: Considering Twitter and Twitter Data for Supply Chain Practice and Research, Int. J. Production Economics, 2015

Capgomeh. (2015). Terdapat di www.capgomeh.wordpress.com/cate gory/artikel/ . Accessed in 2015

Cook, R. A., Yale, L. J., \& Marqua, J. J. (2006). Tourism: The Business of Travel, (3rd ed.). Upper Saddle River, NJ: Prentice Hall.

Chappuis, B., Gaffey, B. dan Parvizi, P. (2011). Are your customers becoming digital junkies?. McKinsey Quarterly, July.

Davidson, R (2011). Web 2.0 as a marketing tool for web conferences centres. International Journal of Event and Festival Management, Vol 2 no 2

Frey, B.S. (1994). The economics of music festivals. Journal of Cultural Economics, 18 (1), 29-39
Getz, Donald. (2008). Event tourism: Definition, Evolution, and Research. Tourism Management, 29, 403-428

Herrero, L. C. J. A., Bedate, A., \& del Barrio, M.J. (2012). Who pays more for more for a cultural festival, tourist or locals? A certainty analysis of a cintingent valuation application. International Journal of Tourism Research, 495-512.

Hudson, Simon and Rupert Hudson (2013). Engaging with consumers using social media: a case study of music festivals, International Journal of Eventy and Festival Management, Vol 4 no 3.208

Hudson, S., Roth, M.S., Madden T.J., \& Hudson, R. (2015). The effects of social media on emotions, brand relationship quality, and word of mouth: An empirical study of music festival attendees. Tourism Management, 47 (0), 68-76, doi: 10.1016/j.tourman.2014.09.001

Kaplam, A.M. \& Haenlein, M. (2010). Users of the world, unite! The challengees and opportunities of social media. Business Horizons, Vol. 15 Nos 2/3. 139-155

Lee, Ji Yeon., Investigating the Effect of Festival Visitors' Emotional Experiences on Satisfaction, Psychological Commitment, and Loyalty. Disertasi. Texas A\&M.

SocialMediaToday. (2015). www.socialmediatoday.com/socialnetworks/201504-13/worlds-21-mostimportant-social-media-sites-and-apps2015. accessed in 2015 
Throsby, C, D. (2003). Determining the value of cultural goods: How much (or how little) does cintingent valuation tell us?. Journal of Cultural Economics, $27,275-285$

Twitter. (2015). Terdapat pada www.twitter.com. Accessed in 2015
Zhang, B and Marita Vos (2014). Social media monitoring: aims, methods, and challenges for international companies, Corporate Communications. An International Journal, Vol 19, no 4. 